\title{
The Role of Teacher Education in Improving Quality Education for a Functional Society
}

\author{
Rowell Ubogu \\ Institute of Education, \\ Delta State University, \\ Abraka, Nigeria
}

Doi: 10.36941/jesr-2020-0o28

\begin{abstract}
The role of teachers' education in improving quality education for a functional society is a paper-based upon the need to reiterate the essence of teacher education in Nigeria. The study adopted the use of two research questions, tested using mean, and two hypotheses also tested using Pearson Correlation and t-test statistics. A questionnaire designed with an internal consistency of o.89 coefficient using Crombach Alpha was administered to lecturers and students from three (3) Colleges of Education (Namely, College of Education Warri, College of Education, Agbor, and College of Physical Education, Mosogar) all in Delta State, and a sample size of 174 was derived based on the number of questionnaires retrieved. The finding of the study revealed that Teacher education contributes to quality education in the Nigerian Society when educationist is acknowledging as a source of reference as custodians of knowledge and as a consultant to consultants. It further demonstrated that there is a statistically significant correlation between teacher education in enhancing quality education and a functional Nigerian Society. It was established that teacher education is the channel for achieving not only educational goals (quality education) but also industrialization, which implies a successful and functional society. The researcher recommends that a feedback mechanism be put in place by the government, policymakers and educational stakeholders to actualize implementation of educational policies on teacher education.
\end{abstract}

Keywords: Functional Society, Quality Education, Role, and Teachers Education

\section{Introduction}

Quality education holds the key to productivity and functional society. Investing in quality teacher's education is crucial for achieving sustainable development, poverty eradication, equity and inclusiveness (UNESCO, 2012). Education is the key to future Africa competitiveness. It is essential for emerging economies such as Nigeria, South Africa, Ghana, etc. to invest heavily in teachers' education to put the African country's economies on the path to sustained growth and development. Research conducted by the United Nations Educational, Scientific and Cultural Organisation (UNESCO) exploring the future of all levels of education in the developing world, found that sustainable education is an index of quality education. It equips individuals with the relevant skills needed to contribute to the development of society (UNESCO, 2012). In fact, in the quest for development, nations have acknowledged that investing in higher education is a must if sustainable development is to be achieved (Akinsaya, 2007).

According to emerging economies in Africa and worldwide (such as Russia with the highest 
adult literacy rate of $99.7 \%$, followed by India 71.2) as recorded by Esposito, 2016), considering the level of investments in the lower level of education, it is expected that the labour force will be equipped with useful skills needed for high productivity.

A major challenge posed to any system is continual sustenance and functional integration of the independent components of the system. The Nigerian educational system is without a doubt an excerpt of such a system, as it relies heavily on teachers as its functional components. Mukhtari (2007) points out that one of the essential truths in education is that the standard of education depends to a great extent the quality of the teacher.

The concept of education has been defined differently by several authorities to such an extent that there cannot be any mutually exclusive definition of what it is.

However, some of these definitions include features like the acquisition of knowledge, skills, abilities and character, training involving guide towards the development of the learners (Abdulsalam \& Issa, 2011). Education, therefore, can be referred to as the procedure by which each successive age learns the accumulated knowledge of their community, the transmission of which was necessitated by the need to enable people to fit into the existent pattern of life and associate with others in a predictable, efficient and humane way.

Teacher education involves the preparation of prospective teachers so that they can use their knowledge and skills to contribute to national development. In this regard, teacher education refers to the professional education of teachers towards attaining attitude, knowledge, and skills for productivity and in line with societal demands. Osuji (2009: 296) explained that teacher education includes "training/education of service (pre-service) and education/training during service (in-service or on the job)". Nakpodia and Urien (2011: 350-356) added that it is "the process which nurtures prospective teachers and updates qualified teachers' knowledge and skills in the form of continuous professional development".

In line with the aforementioned, Teacher education, therefore, constitutes a prominent element in the totality of organized education in a multidimensional sphere of both formal and non-formal structure. Thus, from the definition of teacher education, it connotes teachers are key personnel in realizing the natural goal of a knowledgeable society, portraying them as lifelong learners themselves shouldering the heavy responsibility of their profession and exerting influence on their students.

Kolo (2009) added that the inference from this is that the effective operation of the education system requires that qualified teachers be available in sufficient numbers at different levels of the system to meet the needs of the nation.

The National Policy on Education underpinned this fact stating that "Teacher education will continue to be given a major emphasis in all educational planning because no education system can be above the quality of its teachers". The policy document reiterated further, the need for all teachers in the nation's education sector to be exposed to professional training and development (FRN, 2004).

Okafor and Obienyen (1996) decried, teacher education in Nigeria is already losing its quality as identified in the non-productivity of those products that acquire certificates. Qualitative and functional education is the only viable tool for sustained national development. In this regard, there is a need for proactive partnership between the public and private investors to ensure meaningful and steady investment in every aspect of teacher education. No meaningful development can be attained through teacher education without regular and massive investment. If Nigeria is to attain the vision 2020 millennium developmental goal, then the already ailing teacher education institutions are to be salvaged through improved and constructive investment.

The role of teachers in the development of the nation can never be overemphasised, considering their contribution to nation-building through the advancement of knowledge and skill acquisition. It is also worthy of note, that it is also dependent upon the nature of the society in which it plays its part, and determined by the philosophy which implicitly or explicitly governs relations between the individuals and the community (Abdulsalam and Issa, 2011). 


\subsubsection{Conceptualizing Functional Society}

The nature of the society, therefore, cannot be ostracized from the context of a functional society as it connotes the innate characteristics of the educational system in practice, its introduction, and sustenance based on the premise of human capital development.

Within the Nigerian educational context, and before the introduction of formal western education, individuals had their educational system based on their trade or commercial disposition. Fafunwa (as cited in Ololube, 2006) stated that education equips individuals with social norms and traditions as well as the acquisition of skills for useful living in the society.

Knowledge was being taught directly to learners, with parents and guardians considered as direct custodians of knowledge being taught themselves in their younger years by past generations or masters in the same craft or vocation thereby imbibing a form of human resource developmental professional knowledge paradigm without any form of curriculum, achieving stability consciously or unconsciously having a basis on the simple goal of being trained to function within the society.

Since the 1970s, the study of the teacher's professional knowledge has gotten new driving forces because of increased consideration of the behaviour of teachers. The purpose of the training is to equip with the skills needed for the teaching and learning process (Fenstermacher \& Richardson, 1993; Tom \& Valli, 1990). Türkkahraman (2012) explained that within the relationship between education and society, the most salient feature of education (based on the professional practice developed by the teachers) is its communal side; and that it affects not only the person being educated but also the whole community. Carr and Kemmis (1986) stated that the essence of education is the preservation of social stability through the socialisation of young citizens.

\subsection{Statement of the Problem}

A very close examination of the formulation of policies with regards to education shows that the federal government of Nigeria acknowledges teachers as individuals who implement educational policies, and as such promote the quality education for the development of the nation. But unfortunately, there appears to be a "worm-hole" in the smooth running of these policies and indeed, resulting in the production of a great deal of unmotivated and frustrated teachers. The functionality of education in Nigeria connotes the use of education to solve social problems, emanating from illiteracy, unemployment, teachers' inefficiency and infrastructural deficit (Ikeotuonye, 2003). Inferring logically, therefore, that there is a neglect of teacher education towards the development of the nation.

\subsection{Objectives of the study}

The study, therefore, attempts to investigate;

1. whether or not teacher education adds to quality education in the Nigerian Society

2. the difficulties of teacher education in enhancing quality education in Nigeria

\subsection{Research Questions}

1. Does teacher education contribute to Quality Education in the Nigerian Society?

2. What are the difficulties of teacher education for quality education in Nigeria?

\subsection{Research Hypotheses}

Hypotheses Ho1: There is no significant connection between teacher education in enhancing quality 
education and a functional Nigerian Society.

Hoz: There is no significant difference between male teachers and female teachers contribution to quality education in a functional society

\section{Literature Review}

Education is the critical area whose performance specifically influences and even determines the quantity and magnitude of Africa's development (UNESCO: 2008).

Quality Education is the key to sustainable national development. It serves as a potent tool to stimulate the development of the economic, politic, sociological and human resources of a nation. According to the Nigerian national policy on education (FGN 2004), education is an instrument "par excellence" for effecting national development.

In line with the above assertion, a summit was convened in July 2009, to tackle the problem of teacher education in South Africa. The offshoot of the summit is the need to develop an action plan for teacher development in the country. The plan was integrated into the strategic planning framework for Teachers Education and Development (2011-2025) (Robinson, 2016).

To improve teaching and learning in South African for a functional society (Robinson, 2016). UNESCO (2008) posited that investing in quality teacher education is a vital tool for achieving functional society, which allows every human being to acquire the knowledge, skills, attitude, and qualities important to shape a sustainable future.

It has been identified that the teacher is the key factor in the educational delivery process, as no educational framework outperforms the quality of its teachers. The availability of quality teachers at the lower levels will help to improve the quality of inputs at the higher level and consequently impact positively on the output at higher levels.

In this regard, the aim of the Teachers Registration Council of Nigeria (TRCN) Mandatory Continuing Professional Development (MCPD) programme include training and empowerment of teachers as well as improving their commitment to the teaching profession (TRCN, 2008). To boost the teaching force in the basic education sub-sector, the Federal Teachers' Scheme (FTS) was established by the Federal Government of Nigeria in 2006, to tackle the problem of inadequate teachers, who are qualified to teach in the basic level of education. Nigeria Certificate in Education (NCE) holders are enlisted for two-year teaching service in public primary and junior secondary schools. The Federal Government pays a monthly allowance of Eighteen Thousand Naira only (N18, ooo.oo) to each participant. A total of three sets of participants have been identified from the scheme to date. The project was funded by the Millennium Development Goals (MDGs) fund. This scheme has gone a long way in improving the teaching staff position in the basic education sub-sector, particularly in the rural and semi-urban schools.

Also, boost their morale for effective teaching for a functional society.

However, considering the present economic condition in developing nations like Nigeria teachers' wages are no longer attracted and cannot be used to manage teacher effort and their effectiveness.

The provision of educational opportunities should enable beneficiaries to participate in bringing about socio-economic changes. This may be achieved if children access 'quality' education that is a result of good-quality teaching and learning. It is therefore critical that, with FPE, children access a 'good' education. This may occur if teachers are equipped with the skill and knowledge to manage and promote effective teaching and learning in large classes.

Effective use and strengthening of professional development structures that could promote collaboration and collegiality of teachers at school levels - in the form of peer coaching, mentoring and team teaching - may be the answer to this. This may ensure the provision of relevant, systematic, continuous, sustainable professional support that can have a long-term positive impact on teachers' practices and consequently on children's learning.

Current studies demonstrates that, amid a devastating socioeconomic framework, Nigerian 
teacher continue to suffer the indignity of being among the country's very lowest-paid university graduates (Adelabu 2005:Eldis, 2008, Ogbodo, 2013), in contrast with graduates of other different disciplines such as law, medicine, engineering, management, information technology, business, and accounting. A current contrast of average yearly income uncovered the pitiful pay procuring position of the Nigerian teacher $(B B C, 2008)$. The yearly profit of a state school teacher was assessed at the US $\$ 1,920$, while those of state hospital doctors and freshly employed oil-firm workers were estimated at the US $\$ 6,720$ and the US $\$ 26,880$ respectively.

Quality Teacher education programmes in Nigeria are laudable and very robust, but these require financial backup to translate them into a quality outcome that is needed for a sustainable economic and social development. Quality teacher education is in the powerhouse of the education industry in Africa and Nigeria particular. If the country is to experience sustainable national development, to keep the economy alive and going, public and private organization must invest massively in the recruitment of profession qualified staff, the re-training and professional development of professional and non-professional staff through conference, seminars, overseas courses, infrastructure, and physical facilities, instructional materials, transport and security service(Ogbodo; 2012).

Otomewo and Oyolu, (2015) posited that to achieve a functioning society through the role of teacher education, there is a need for effective supervision of teacher education.

Without the supervision of the Nigerian education system by both the inspection division of the ministry of education and heads of schools, teacher education will continue to lack quality. Any educational system that lacks quality cannot produce output (graduates) that will be productive towards national development because education is the life wire that promotes economic development.

\section{Methodology}

In this study, the survey design was used with a target population consisting of all lecturers and students from three (3) Colleges of Education (Namely, College of Education Warri, College of Education, Agbor, and College of Physical Education, Mosogar) all in Delta State. using a systematic random sampling technique, a sample size of 174 was established. Mean, Pearson Correlation and ttest were used to analyze the data at a significant level of 0.05 . The instrument was therefore adjudged reliable at a 0.89 coefficient as its internal consistency at a significance level of 0.05 .

\section{Analysis and Discussion}

\subsection{Research Question 1: Does teacher education contribute to Quality Education in the Nigerian Society?}

The research question one was answered using mean;

Table 1: Showing mean of respondents

\begin{tabular}{|c|c|c|c|c|c|c|c|}
\hline Items & $\begin{array}{c}\text { Strongly } \\
\text { Agree }\end{array}$ & Agree & isagree & $\begin{array}{l}\text { Strongly } \\
\text { Disagree }\end{array}$ & FX & $\mathrm{X}=$ Mean & Remark \\
\hline $\begin{array}{l}\text { Being the job of the educationist to trained to develop the } \\
\text { upcoming workforce of the nation }\end{array}$ & 87 & 51 & 32 & 4 & 569 & 3.27 & Agree \\
\hline $\begin{array}{l}\text { acknowledging educationist as a source of reference as a custodian } \\
\text { of knowledge }\end{array}$ & 92 & 49 & 24 & 9 & 572 & 3.29 & Agree \\
\hline Being a consultant to consultants & 77 & 62 & 19 & 16 & 548 & 3.15 & Agree \\
\hline $\begin{array}{l}\text { Being a custodian of Morality and moral guidance in a morally } \\
\text { dilapidated society }\end{array}$ & 83 & 57 & 32 & 2 & 569 & 3.27 & Agree \\
\hline Being a source of income in itself & 61 & 93 & 16 & 4 & 559 & 3.21 & Agree \\
\hline Being the starting point in the creation of National GDP at all levels & 56 & 74 & 38 & 6 & 528 & 3.03 & Agree \\
\hline Group Mean & & & & & & 3.84 & Agree \\
\hline
\end{tabular}


The mean rating of respondents on the question; Does teacher education contributes to Quality Education in the Nigerian Society was answered using mean as shown in Table 1, and based on its mean score the question was answered remarking that the respondents accepted the issues raised as areas teacher education can contribute to Quality Education in the Nigerian Society.

4.2 Research Question 2: What are the challenges of teacher education for quality education in Nigeria?

The research question two was answered using mean;

Table 2: Showing mean of respondents

\begin{tabular}{|c|c|c|c|c|c|c|c|}
\hline Items & Strongly & Agree & isagree & Strongly & FX & $\mathrm{X}=$ Mean & Remark \\
\hline & Agree & & & Disagree & & & \\
\hline Lack of jobs for competent educationist to display their prowess & 65 & 49 & 36 & 24 & 503 & 2.89 & Agree \\
\hline $\begin{array}{l}\text { Inconsistency in the actual execution of governmental policies on } \\
\text { teacher education }\end{array}$ & 82 & 41 & 34 & 17 & 536 & 3.08 & Agree \\
\hline Government policies do not match the needs of society & 44 & 59 & 42 & 29 & 466 & 2.68 & Agree \\
\hline Inaccessibility of governmental officials for feedback processes & 78 & 39 & 26 & 31 & 512 & 2.94 & Agree \\
\hline $\begin{array}{l}\text { society accords low regard for Educationist and is often intimated } \\
\text { and humiliated by rich and wealthy politicians }\end{array}$ & 55 & 48 & 43 & 28 & 478 & 2.75 & Agree \\
\hline Group Mean & & & & & & 2.87 & Agree \\
\hline
\end{tabular}

The above table shows the mean rating of respondents on the challenges of teacher education for quality education in Nigeria was answered using mean. Based on the mean score and the remark it is clear that all the issues highlighted are challenges of teacher education in Nigeria.

\section{Test of Hypotheses}

\section{$5.1 \quad H o 1$}

There is no significant relationship between teacher education in improving quality education and a functional Nigerian Society. Hypothesis one was tested using Pearson Product Moment Correlation coefficient at a 0.05 level of significance

Table 4: Showing the relationship between teacher education in improving quality education and a functional Nigerian Society

\begin{tabular}{|c|c|c|c|}
\hline & & $\begin{array}{c}\text { Teacher Education in } \\
\text { improving quality education }\end{array}$ & $\begin{array}{c}\text { A Functional } \\
\text { Nigerian Society }\end{array}$ \\
\hline \multirow{3}{*}{$\begin{array}{l}\text { Teacher Education in } \\
\text { improving quality education }\end{array}$} & Pearson Correlation & 1 & 0.811 \\
\hline & Sig. (2-tailed) & & 0.050 \\
\hline & $\mathrm{N}$ & 174 & 174 \\
\hline \multirow{3}{*}{$\begin{array}{l}\text { A Functional Nigerian } \\
\text { Society }\end{array}$} & Pearson Correlation & 0.811 & 1 \\
\hline & Sig. (2-tailed) & 0.050 & \\
\hline & $\mathrm{N}$ & 174 & 174 \\
\hline
\end{tabular}

The table reveals the Person Correlation for the relationship between teacher education in improving quality education and a functional Nigerian Society, with a 2 - tailed correlation value of o.811 which implies that as the teacher education in improving quality education increases, the level of functionality of the Nigerian Societal system improves by approximately $81.1 \%$. Confirming this also is its Sig value of 0.050 indicating that there is a statistically significant correlation between teacher 
education in improving quality education and a functional Nigerian Society, being that the p-value $0.050=0.05$ significant level, thus rejecting the hypotheses 1 and accepting the alternative hypotheses.

\section{$5.2 \quad \mathrm{Ho2}$}

There is no significant difference between the male teachers and female teachers' contribution to quality education in a functional society Hypothesis two employed the use of t-test statistic at 0.05 level of significance.

Table 5: Showing difference between male teachers and female teachers contribution to quality education in a functional society

\begin{tabular}{|l|c|c|c|c|c|c|c|}
\hline Variable & N & Mean & Std & Df & $\begin{array}{c}\mathbf{t}- \\
\text { Calculated }\end{array}$ & $\begin{array}{c}\text { t-Critical } \\
(.05)\end{array}$ & Remark \\
\hline $\begin{array}{l}\text { male teachers contribution to quality } \\
\text { education in a functional society }\end{array}$ & 69 & 3.043 & 0.177 & & & & \\
\hline $\begin{array}{l}\text { female teachers contribution to quality } \\
\text { education in a functional society }\end{array}$ & 105 & 2.973 & 0.128 & 172 & 0.1108 & 1.960 & Accepted \\
\hline
\end{tabular}

The t-test for the difference between the male teachers and female teachers' contribution to quality education in a functional society shows a calculated $\mathrm{t}$-value of 0.1108 and $\mathrm{t}$-table value of 1.960 at 0.05 level as shown in table 5. It, therefore, implies that the null hypothesis is accepted that there is no significant difference between the male teachers and female teachers' contribution to quality education in a functional society being that the t-table (1.96) value is greater than $\mathrm{t}$-cal (o.1108) at a o.05 significance level.

\section{Discussion of Findings}

Teacher education contributes to Quality Education in the Nigerian Society as observed from the result of the study since the educationist must develop the upcoming workforce of the nation. Abdulsalam and Issa (2011) reiterate that the essence of the role that the teacher plays in the development of any nation, especially in bringing up future leaders and intellectuals is simply immeasurable. The finding went further to show that Teacher education also contributes to quality education in the Nigerian Society when educationist is acknowledging as a source of reference as a custodian of knowledge and a consultant to consultants. Ekpiken and Edet (2014) support this stating that quality education cannot be achieved without the contribution of qualified and dedicated teachers. On the issue of being a custodian of Morality and moral guidance in a morally dilapidated society, Abdulsalam and Issa (2011) stating that the teacher is the society's trustee in the entire arena of socio-economic, political and moral development, and on being a source of income in itself and the starting point in the creation of National GDP at all levels.

The findings also revealed that Lack of jobs for competent educationist to display their prowess, Inconsistency in the actual execution of governmental policies on teacher education and the fact that Government policies do not match the needs of the society and inaccessible governmental officials for feedback processes were other challenges of teacher education in Nigeria as the researcher highlighted earlier and reiterates that the above were the "worm-hole" hindering the smooth operationality of these policies thereby resulting in the production unmotivated and frustrated teachers in our society. In an ideal situation, teachers are supposed to be the producers of future leaders, thereby guaranteeing $\mathrm{t}$ future, but sadly, teachers have over the years transferred this frustration into demeaning mediocre character portrayed in the classroom leaving society as the victim of the circumstance. 
Also, society accords low regard for educationists as they are often intimated and humiliated by rich and wealthy politicians. Ekpiken and Edet (2014) further recognize this fact stating that the society holds trained teachers at a very low ebb; even worse, teachers at times have been molested and humiliated by some members of society.

The study also found out that there is a statistically significant correlation between teacher education in improving quality education and a functional Nigerian Society, Tahir (1996) in concurrence added that teachers are the ones that make or mar the growth and development of any nation through education. Therefore, the role that the teacher plays in the development of any nation, especially in bringing up future leaders and intellectuals is simply immeasurable (Abdulsalam \& Issa, 2011).

Finally, on gender disparities, the findings revealed that there is no significant difference between male teachers and female teachers' contribution to quality education in a functional society. Osakinle, Onijigin, and Falana, (2010), in a similar study, discovered that there is no notable difference in sex and teaching methods of lecturers, which in this regard refers to educationist and quality education.

\section{Conclusion}

The role of Teachers education in improving quality education for a functional society like Nigeria cannot be overemphasized, as no individual or nation can achieve an objective it is currently unaware of. Thus Teacher education and educationist are the channel for achieving not only educational goals (quality education) but also national development leading to industrialization which is a muchneeded ingredient in the development of the Nigerian economic system.

\section{Recommendation}

Based on the above, the researcher recommends that a feedback mechanism should be put in place by the government, policymakers and educational stakeholders to actualize implementation of educational policies on teacher education. Teachers' development should be followed by an adequate motivational package.

\section{References}

Abdulsalam, AU \& Issa AO. (2011). Teachers' Roles in Qualitative Education. retrieved from www.unilorin.edu.ng retrieved date: 5 th November 2015

Adelabu, M.A. (2005) Teacher Motivation and Incentives in Nigeria. Available online at www.eldis.org/vfile/upload/1/document/o709/ Teacher motivation Nigeria.

BBC (British Broadcasting Corporation) 2008. Nigeria: Facts and Figures. Available online at http://news.bbc.co.uk/2/hi/africa/6508055.strn (accessed 9 January 2008).

Eldis. 2008. Teachers' Voice: A Policy Research Report on Teachers' Motivation and Perceptions of their Profession in Nigeria. Available online at www.vso.org.uk/lmages/vt_nigeria_teachers_voice_tcm8-14649.pdf (accessed 6 June 2008).

Ekpiken WE. \& Edet AO. (2014). The Role of Teacher Education and Nigerian Teachers in National Development: The Way Forward. Higher Education of Social Science, 7(1), 139-143.

Federal Republic of Nigeria (2004). National Policy of Education. Lagos: National Educ. Res. Dev. Council

Ikeotuonye, AI. 2013. Preparing teachers for the Challenges of Nigeria Vision 20:2020. https:// www.slideshare.net/talk.2sp

Nakpodia E.D. \& Urien. 2011. Teacher Education in Nigeria: Challenges to Educational Administrators in the 21st Century. The Social Sciences, 6(5), 350-356.

Ogbodo, PO. 2013. Investment in Quality Teacher Education for Sustainable development. Nigeria Association for Educational Administration and Planning. Delta State University, Abraka, University Printing Press 
Okafor, EN Obienyem, C. 1996 Quality in Teacher Education in Nigeria. The threat of Examination malpractice in Teacher Education. In P. N. Lassa, C. M. Anikweze and A. A. Maiyanga (eds). Imperative for National Development. Nigeria: Kaduna, NCCE.

Osakinle EO., Onijigin EO. \& Falana, BA. 2010. Teaching Methods and Learners' Environment in a Nigerian University. African Journal of Basic E Applied Sciences, 2(1-2), 7-10.

Robinson M. 2015. Teaching and Learning together. The establishment of Professional Practice schools in South Africa. A research report for the Department of Higher Education and Training. Stellenbosch University.

Tahir G. 1995. The Teachers in the Contemporary Society. (A Seminar paper)

Teachers' Registration Council of Nigeria (TRCN). 2018. Manual of the Mandatory Continuous Professional Development Programme. Abuja: TRCN.

UNESCO 2008. Sustainable Development Report on Africa: Five Year, Review of the Implementation of the World Summit on Sustainable Development Outcome in Africa, Addis Ababa, Ethiopia. 